\title{
Moving towards Entrepreneurial Translator Education: a Review of Entrepreneurship Competence in Spanish Translator Education Programmes
}

\begin{abstract}
This paper reviews the entrepreneurship competences included in the curricula of undergraduate translation and interpretation degrees in Spain to determine whether they explicitly or implicitly match the competences included in the EntreComp framework. Our review reveals that the EntreComp entrepreneurial competences are underrepresented in current curricula in Spain, with some remarkable exceptions, particularly regarding the 'resource management' and 'learning by doing' competences. The SWOT analysis performed using the results derived from the descriptive analysis of the collected data suggests that the spotted strengths and opportunities can compensate for most of the weaknesses. Accordingly, it is our claim that an entrepreneurial approach to education that is compatible with the Entrepreneurship 2020 Action Plan can be introduced in Spanish translator education programmes within the current framework.
\end{abstract}

\section{Keywords}

entrepreneurial education; entrepreneurship competence; EntreComp Framework; Entrepreneurship 2020 Action Plan; translator education

\section{Introduction}

In 2006, the European Parliament and Council released a Recommendation on key competences for lifelong learning, one of which was "sense of initiative and entrepreneurship" (European Parliament and Council 2006). This was the onset of a change in European education aimed at improving educational attainment levels and equipping students for the adult life. At that time, the sense of initiative and entrepreneurship competence was broadly defined as the individual's ability to turn ideas into action (European Parliament and Council 2006: 17). The main components of the competence were already identified and mentioned, but not explained in detail. In 2013, the Entrepreneurship 2020 Action Plan acknowledged the benefits of entrepreneurial learning for young people, independently of whether they planned to create their own business. It also claimed that entrepreneurial learning contributes to developing business knowledge and essential skills and attitudes needed to transform ideas into action and increase employability, among which creativity, initiative, tenacity or teamwork (European Commission 2013). Likewise, the Entrepreneurship 2020 Action Plan acknowledged the need for Universities to be more entrepreneurial, also in non-business studies, giving a boost to the definition of a common entrepreneurship competence framework model, also known as EntreComp, that could be used as a reference. Throughout this process, the European Union started a number of entrepreneurial projects and programmes for the development of the entrepreneurial competences across all education levels, and particularly in higher education (European Commission 2006, 2008a, 2008b, 2012, 2015, Eurydice 2012, Komarkova et al. 2015).

Under this approach, entrepreneurship is not necessarily aimed at creating a new venture or organisation, as claimed by Shane and Venkataraman (2007), thus deviating from a narrow view of entrepreneurship, aimed exclusively at becoming an entrepreneur (Lackéus 2015: 9). Rather, entrepreneurship can occur within an existing organisation and can be linked to the learner's en-

* María Teresa Veiga Díaz

Department of Translation and Linguistics

University of Vigo

E-mail:mveiga@uvigo.es 
trepreneurial mind-set and behaviour. It can also aim at becoming entrepreneurial, which would involve a wide approach to entrepreneurship. The wide approach involves working competences related to personal development, creativity, initiative taking and action orientation, which is in agreement with the approach of the EU (Komarkova et al. 2015: 4).

Our hypothesis in this research is that the components of the entrepreneurship competence can be further developed in translator education programmes within the current framework to create value for external stakeholders by letting students create value, whether it is successful or not. Thus, our research aims to review the entrepreneurship competences included in the curricula of undergraduate translation and interpretation degrees in Spain and determine whether they explicitly or implicitly match the competences included in the EntreComp framework; to explore the strengths, weaknesses, opportunities and threats of the current situation of entrepreneurial translator education in Spain; to determine which approach is adopted with regard to entrepreneurial education, and to make proposals for introducing an entrepreneurial approach that fits the Entrepreneurship 2020 Action Plan.

\section{Entrepreneurship: definition and components}

The entrepreneurship concept developed in the field of economy to refer to the ability of those people willing to take risks, face uncertainties, perform innovations and create new businesses (Souza 2001). This has been the prevailing interpretation of the term, which has usually been researched in the management and business sector in relation to the creation of new ventures and enterprises (Gartner 1990, Klerk/Kruger 2002, Aruwa 2006, Drucker 2007, Mesquita et al. 2016: 225). Within this framework, many authors focused on the importance of developing soft skills related to leadership, moral values and ethics, communication, and also on the ability to adapt to new work contexts, as reported by Sousa (2018: 3). Yet, the complexity of the concept, which has been widely acknowledged (GHK 2011: 10, Del Giudice 2014: 128, Mesquita et al. 2016: 224), together with the need to expand the concept and extend it to other fields, has led many scholars to attempt to find an accurate definition covering all the traits and competences involved. However, no consensus has been reached (Redford 2015: 19). Currently, this approach to entrepreneurship is seen as a 'narrow' approach, which considers that entrepreneurship is about business development, self-employment, and venture creation and growth. Yet, there is an increasingly relevant 'wide' approach to entrepreneurship, particularly in the educational domain, according to which entrepreneurship is about personal development, creativity or initiative taking, among others, i.e. being entrepreneurial but not necessarily becoming an entrepreneur (Komarkova et al 2015: 9).

In line with the wide approach, the European Union (EU) has defined entrepreneurship as a key transversal competence for lifelong learning (European Parliament and Council 2006) that applies to all spheres of life and is necessary for all members of the current knowledge-based society. As suggested by Mwasalwiba (2010), choosing a given approach to entrepreneurship profoundly affects educational objectives, course design or teaching methods. In this paper, we will adopt the wide approach to entrepreneurship, which assumes that entrepreneurship education goes beyond preparing students on how to run a business, and that it involves helping develop the entrepreneurial attitudes, skills and knowledge that enable students to 'turn ideas into action' (European Commission 2014: 9).

Defining the attitudes, skills and knowledge required to be entrepreneurial has often been difficult, and efforts to define such skills have often come, again, from the management and business sector (Sousa 2018). Yet, evidence has been found that it is possible to identify a set of skills that are distinct from management or leadership skills and that such skills can be taught and learned (BIS 2015: 5, Mesquita et al. 2016: 223). However, no agreement has been reached with regard to the composition of such set of skills, as there are many views on the exact components of the entrepreneurship competence. For example, the Department for Business, Innovation and Skills (BIS) categorised them into four categories, namely, idea identification/creation, capitalising on ideas, traits/behaviours and managerial/leadership skills (BIS 2015). However, also in the UK, 
the International Institute for Creative Entrepreneurial Development (IICED) identified a different set of competences: communication, visioning and thinking creatively, opportunity identification, self-efficacy, self-knowledge and belief, confidence and determination, flexibility and adaptability (Komarkova et al. 2015: 233). In Spain, the Ministry for Industry, Commerce and Tourism (MICT) offers a self-diagnosis tool for entrepreneurs based on seven dimensions: motivation, initiative, communication, analysis, risk, leadership and creativity (MICT 2019). These are only a few examples of the diversity of views found in the field of entrepreneurship competence components that illustrate the challenges of introducing these components in all education levels across Europe.

To face this challenge, the European Commission has proposed a common framework for the development of entrepreneurial competences, which is aligned with learning outcome descriptors that can be used as a reference for the design of curricula in the formal education and training sector (European Commission 2016). The EntreComp framework aims to define a common understanding of the entrepreneurship competence, and defines three interrelated and interconnected areas of competence, namely 'ideas and opportunities', 'resources' and 'into action', and a list of 15 competences as a reference for current and future initiatives. The labels assigned to each area aim at stressing that entrepreneurship competence is the ability to transform ideas and opportunities into action by mobilising resources. Figure 1 represents the structure of the three competence areas.

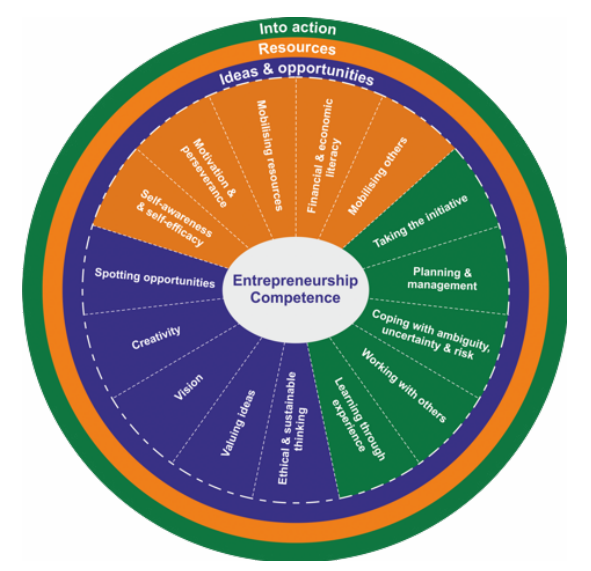

Figure 1. Entrepreneurial competence and competence areas according to EntreComp (Source: European Commission 2016: 6)

\section{Entrepreneurship in education}

The approaches to and challenges of the development of a common definition of entrepreneurship and entrepreneurship competence described in the above section can be transposed to the education field, particularly to higher education. Ten years ago, entrepreneurship education in Europe concentrated on economics and business courses at university level, but very few universities included entrepreneurship as a transversal competence for the different programmes (EMFD 2008: 43). At that time, Spanish universities focused on promoting the enterprise spirit in general courses in business management and undergraduate degrees related with business management (EMFD 2008: 23). Likewise, new undergraduate degrees started being implemented. These new degrees met the requirements of the European Higher Education Area, which involved considering a sense of initiative and entrepreneurship as a key competence for lifelong learning (European Commission 2006) and incorporating innovation, creativity, and entrepreneurship skills into transversal competences, learning methods and assessment methods (MECD 2015: 13).

As stated in the introduction, a number of entrepreneurial projects and programmes for the development of the entrepreneurial competences in higher education were implemented between 
2006 and 2019 (European Commission 2008a, 2008b, 2012, Komarkova et al. 2015). Currently, the results of the implemented entrepreneurship programmes reveal a lack of conclusive results, which is a common drawback in the assessment of the effectiveness of entrepreneurial education. Neither quantitative nor qualitative analyses have confirmed or refuted the utility of entrepreneurial education (Lackéus 2015: 19, European Commission 2015) or concluded which methods address entrepreneurship competences more effectively (Blenker et al. 2014, Komarkova et al. 2015: 4). Nevertheless, the literature suggests increasing qualitative evidence of the effectiveness of entrepreneurial education, which impacts individuals, educational institutions, the economy and society (European Commission 2015: 6). Similarly, research reveals some common patterns, such as the prevalence of learning-by-doing and collaborative approaches to learning, the need for connection to the outside world and the inadequacy of traditional learning (Sousa 2018). Actually, strong evidence has been found that conventional teaching and learning is less effective than task-oriented approaches that include experiential learning and learning through interaction with peers (BIS 2015: 19-20).

Despite all the stated positive effects of entrepreneurship education, putting it into practice has often posed significant challenges, as suggested by Pihie and Bagheri (2011), Lackéus (2015) or Redford (2015), often because of the lack of time and resources or because teachers fear commercialism, as entrepreneurship has been primarily viewed from an economic perspective because of its positive effects on employment, productivity, innovation and economic growth (Sousa 2018: 2). Similarly, the literature reveals insufficient teacher training and the need for a more holistic approach in this respect (Lackéus 2016, Komarkova et al. 2015), despite the fact that the success of entrepreneurial education programmes has been commonly attributed to teachers' high level of engagement (European Commission 2008: 40, European Commission 2015: 13).

Another major challenge to implementing entrepreneurial training relates to assessing to what extent the relevant competences have been acquired, which is the least advanced aspect of this issue. Assessment efforts often focus on the acquisition of competences or even on its effects on employability, but should focus on the activity developed and should be based, according to Lackéus (2016) on actions, thoughts and emotions. Such strategies can be better implemented by teaching through entrepreneurship instead of teaching for entrepreneurship, which results in learning by creating value, instead of merely learning by doing. Whereas teaching for entrepreneurship involves an occupationally oriented approach based on the acquisition of the required knowledge and skills, teaching through entrepreneurship is based on an experiential approach that can be integrated into other subjects by connecting the entrepreneurial competences to the core subject (Lackéus 2016: 10). This approach leads us to constructive alignment, in which assessment is aligned with the tasks that must be carried out to achieve the relevant learning outcomes (Biggs/Tang 2011), and which was proposed by Veiga Díaz/García González (2016) as an integral approach to translation teaching and learning. Within this approach, a progression model would be required that allows teachers to gradually adapt the learning process according to learners' progress. Lackéus (2016: 24) concludes that four dimensions must be incorporated in entrepreneurial learning in order to achieve progression:

- Team-based approach.

- Focus on value creation.

- Connecting students with the outside world.

- Letting students act on their knowledge and skills.

Incorporating these dimensions into the teaching and learning process leads to the acquisition of entrepreneurial competences but, as already stated, teachers do not always receive advice on how to apply these approaches or what to let students do. 


\section{Entrepreneurship in translator education}

In the field of translator education, the literature reveals an increasing interest in specific aspects of entrepreneurial education, namely employability, and in bridging the gap between professional practices and training in Spain, particularly over the last few years (Calvo et al. 2010, Chouc/Calvo 2011, Galán Mañas 2017, Olalla Soler 2019). In this context, some authors have focused on exploring the market (Rico Pérez/García Aragón 2016), whereas others have delved into the professional competences required to enter that market (Álvarez Álvarez/Arnáiz Urquiza 2017, Galán Mañas 2019). Álvarez Álvarez/Arnáiz Urquiza (2017) focused on integrating in the curricula the professional competences required to enter the market, such as project management, social networking, taxes and invoicing, and concluded that these competences are underdeveloped in Spanish curricula and that students should be provided with more tools to match the market needs.

The research conducted in translator education and employability is extremely valuable and relevant to entrepreneurial competence, and it has been useful in the production of a new European competence framework aimed at consolidating and enhancing the employability of graduates of Master's degrees in translation through Europe (European Commission 2017). Yet, employability is only one of the areas of impact of entrepreneurial education. Thus, Torres-Hostensch (2012) analysed whether Spanish translation postgraduates were prepared for employment and concluded that knowledge of the market was not sufficient, and that specific knowledge, skills and attitudes were required for the students to succeed. Similarly, King (2016) analysed employability in translator education and found that, despite the curriculum being increasingly designed with market needs at its core, few learners undertaking translator education programmes intended to work as full-time professional translators. Consequently, she highlighted that translator education programmes should include employability skills that are flexible and relevant to varied labour markets, which would prepare learners for chaotic careers. Gieure Sastre (2016) analysed the 'survival' of self-employed translators and interpreters and of translation and interpretation firms from the perspective of entrepreneurship and found that entrepreneurial education is an indicator of business success both for business owners and self-employed translators because such training can have a real and lasting impact. Indeed, entrepreneurial education goes beyond employability and aims at equipping students with the key set of competences needed for personal development, social inclusion, active citizenship and employment. Galán Mañas (2019) suggested pedagogical tools to acquire such competences, particularly the use by teachers of professional portfolios as a tool to assess students' professional competences, and concluded that the professional portfolios help students identify their own general competences and set future goals, which are related to the 'vision' and 'self-awareness and self-efficacy' competences envisaged in the EntreComp framework. In the field of self-efficacy, some steps have been taken in translation pedagogy research in the last few years. Thus, Bolaños Medina (2014) introduced the concept of self-efficacy from a social and cognitive perspective and found that self-efficacy is a construct of relevance for translation process-oriented research that has shown positive correlations with participants' proficient language comprehension, tolerance of ambiguity and documentation abilities. Based on this research, Bolaños Medina/Nuñez (2018) proposed a preliminary scale for assessing translators' self-efficacy. Haro Soler (2017) performed a study to find ways to incorporate self-efficacy in translator training programmes and identified some practices that help develop translation students' self-efficacy, among which: positive and constructive feedback, a student-centred approach based on strategy learning, continuous assessment, promoting participation and promoting awareness of student performance. More recently, Haro Soler (2019) claimed that collaborative work positively affects students' self-efficacy beliefs because of the possibility to discuss solutions and processes among peers, while Haro Soler/Kiraly (2019) explored self-efficacy beliefs in an action-research project in which students collaborated with teachers and researchers.

The above proposals focus particularly on two areas of the EntreComp framework, namely 'resources' and 'into action', and highlight the interrelation between the 'working with others' and 'learning through experience' components of the entrepreneurship competence and the 
development of other components, such as 'self-efficacy' or 'tolerance of ambiguity'. Actually, both dimensions have often been combined under project-based learning or collaborative learning, which focuses on processes rather than on outcomes. As suggested by Massey/Braendli 2016, collaborative projects in translator education are designed to expose students to the processes, actors and factors of the situated translation event, fostering learner autonomy, self-awareness and empowerment. In line with this approach, Kiraly (2016) presented various innovative proposals for authentic experiential learning in translator and interpreter education claiming that authentic experiential work is an effective platform for learning. Actually, research on collaborative learning through experience and its related benefits is really abundant in the field of translation pedagogy. Huertas (2011), Kiraly (2012), Huertas (2013), Mitchell-Schuitevoerder (2013), García González/Veiga Díaz (2015), Hagemann (2016), Kiraly et al. (2016), Maruenda Bataller/Santaemilia Ruiz (2016), Massey (2019) or Kiraly et al. (2019) are only a few examples of how the social-constructivist approaches to translator education have evolved into a comprehensive view of learning that rejects conventional one-way, top-down transmission of knowledge and skills and uses experience in collaboration with others to develop a whole set of competences, including the entrepreneurial competences envisaged in EntreComp, insofar as teaching through entrepreneurship is based on an experiential approach that connects the entrepreneurial competences to the core subject (Lackéus 2016: 10).

\section{Methodology}

To determine whether the components of the entrepreneurship competence envisaged in EntreComp can be further developed in current translator education programmes in Spain, we carried out a descriptive analysis of the entrepreneurship competence as represented in the curricula of such programmes. First, we determined the extent to which the 31 Spanish Universities offering Translation and Interpretation undergraduate degrees incorporate the EntreComp Framework Competences in their curricula. To this end, we reviewed the competences included in the curricula of the 32 undergraduate degrees in Translation and Interpretation in Spain and we collected information on the following parameters:

- Name of university.

- Type of university, according to the public-private dichotomy, which would be relevant for policing.

- Name of degree, in order to determine whether the curriculum was interdisciplinary or focused exclusively on translation and interpretation.

- Year of degree implementation, in order to determine whether the curriculum was designed and implemented prior to or after the Entrepreneurship 2020 Action Plan and, consequently, the development of the EntreComp Framework.

- Incorporation of transversal competences, in order to determine whether the competences envisaged in the curricula are considered as transversal for life or related exclusively to the relevant degree.

- Inclusion of a broad entrepreneurship competence or of specific EntreComp competences, in order to determine the extent to which the relevant entrepreneurial competences are considered.

Because EntreComp is envisaged as a flexible source of inspiration (EntreComp 2016: 5), we adopted a flexible approach and completed the analysis by recording those competences that slightly deviated from the explicit definition provided in EntreComp. Thus, we recorded the competences that coincided partially with EntreComp competences and those which were applied exclusively to translation, and analysed them separately. Hence, we differentiated the competences that fully matched the EntreComp competences and the competences that only partially did, with a view to determining which aspects of entrepreneurship are actually envisaged in current Spanish translation programmes. 
In addition, we determined the kind of approach adopted by translator education programmes to entrepreneurial education by reviewing all the curricula. Specifically, we revised whether the EntreComp competences were incorporated in translation education programmes as competences that are transversal to the programme ('learning through entrepreneurship') or as competences that are specific to certain modules ('learning for entrepreneurship').

Based on the results of the review, we performed a SWOT analysis to identify the strengths and weaknesses of the current curricula, as well as the opportunities and threats that should be considered for taking action. SWOT is a descriptive tool used to obtain an overview of an organisation's environment by evaluating internal strengths and weaknesses, and external opportunities and threats (Sammut-Bonnici/Galea 2015: 1). The results of the analysis were used to make an overall proposal for introducing entrepreneurial training in undergraduate translation degrees in Spain within the current curricular framework.

\section{Entrepreneurial competences for Translators in Spanish Universities}

In Spain, a total of 31 Universities offer 32 undergraduate translation degrees, 21 of which are taught in public universities $(65 \%)$ while 11 are taught in private universities $(35 \%)$. Interdisciplinary degrees are uncommon; actually, $75 \%$ focus exclusively on translation and interpretation, while $15 \%$ combine translation with languages and $10 \%$ combine translation with communication. Combining translation with languages or communication is more frequent in private universities, which offer $62.5 \%$ of interdisciplinary degrees. This means that $85 \%$ of the degrees offered by public universities focus exclusively on training translators and interpreters, whereas $15 \%$ of the degrees are aimed at training translators and language teachers.

With regard to the year of implementation of the analysed curricula, two thirds of the degrees were implemented between 2008 and 2013, before the release of the Entrepreneurship 2020 Action Plan and the development of the EntreComp framework model, and only one third was implemented between 2014 and 2019. Within the latter, a distinction must be made between preEntreComp and post-EntreComp degrees: 50\% of the degrees implemented between 2014 and 2019 are pre-EntreComp and 50\% are post-EntreComp. In terms of entrepreneurship competence, this means that $80 \%$ of current degrees were designed according to the broad definition of entrepreneurship competence contained in the Recommendation of the European Parliament and the Council as a key competence for lifelong learning (European Parliament and Council 2006: 17), and only $20 \%$ of the curricula were designed after the establishment of a common framework for entrepreneurship competence development. Particularly, $12.5 \%$ of post-EntreComp curricula were designed and implemented by private universities and only $7.5 \%$ of post-EntreComp curricula were designed by public universities, which could be due to greater competition for attracting students through modernisation and differentiation.

The impact of these findings on designing and deploying entrepreneurial competences in translator education in Spain is clear: our review has revealed that entrepreneurship in translator and interpreter education in Spanish universities is often seen as a competence per se. Actually, 37.5\% of the undergraduate degrees include 'Taking the initiative and entrepreneurship' as a transversal or general competence, and some of the degrees combine this competence with other competences such as motivation, coordination or leadership. This wording matches the $2006 \mathrm{Re}-$ commendation to include the sense of initiative and entrepreneurship as a key competence, but ignores its components, which already emerged from the 2006 description of the competence, despite their germinal state. Interestingly, one of the curricula that incorporated the sense of initiative and entrepreneurship competence was designed after 2016, thus neglecting the EntreComp framework. Figure 2 shows the distribution of EntreComp competences according to period of curricula design and implementation. Before 2013, only six of the EntreComp competences were considered in the curricula. After the release of the Entrepreneurship 2020 Action Plan, five new competences emerged in the curricula, namely spotting opportunities, valuing ideas, ethical and sustainable thinking, self-awareness and self-efficacy, and financial and economic literacy. Yet, 
with the emergence of these competences, the presence of four of the competences included in previous curricula declined, with no recognisable pattern in most cases, except for 'planning and management', which from 2013 has been considered exclusively from the point of view of managing translation projects in $33 \%$ of cases.

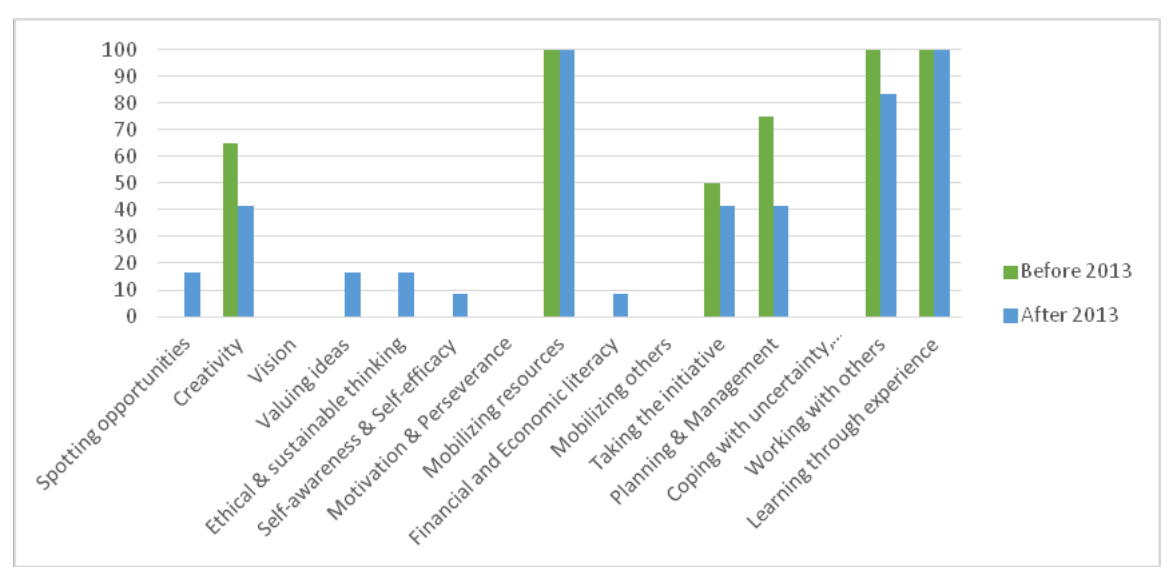

Figure 2. Distribution of competences according to period of curricula design and implementation.

Given that EntreComp defines entrepreneurship as a transversal competence that applies to all spheres of life, we have checked whether the translator education curricula currently in force in Spain envisage the development of transversal competences in general, i.e. any competences that are relevant for life and must be developed across education levels and sectors. We found that only $53 \%$ of the degree curricula explicitly incorporate transversal competences, a proportion that has improved only slightly over time, as 58\% of the degrees implemented after 2013 have incorporated transversal competences into their curricula, but $41 \%$ still ignore transversal competence development. No significant differences were found between public and private universities for this parameter, though the percentage of public universities incorporating transversal competences into their curricula was slightly lower $(52.4 \%)$ than the percentage of private universities $(54.5 \%)$.

More specifically, the analysis of the categorisation of the EntreComp competences included in Spanish translator education curricula reveals that only $42 \%$ have been categorised as transversal, i.e. considered by curricula designers as transferable to all spheres of life, whereas $54 \%$ have been categorised as general, i.e. considered by curricula designers as common to various modules in the same degree, and $4 \%$ have been categorised as specific, i.e. exclusive to a given module. This suggests that the majority of the degrees have disregarded the EU Recommendation, which considers entrepreneurship as a transversal competence. According to this Recommendation, all the components of the entrepreneurship competence should have been categorised as transversal, which contrasts with the fragmentation of results shown in Figure 3. This means that current Spanish curricula are approaching translator education from the inside, without equipping future translators for personal development, work life or the outside world. Thus, Spanish translator education degrees educate future translators for entrepreneurship, but not through entrepreneurship. 


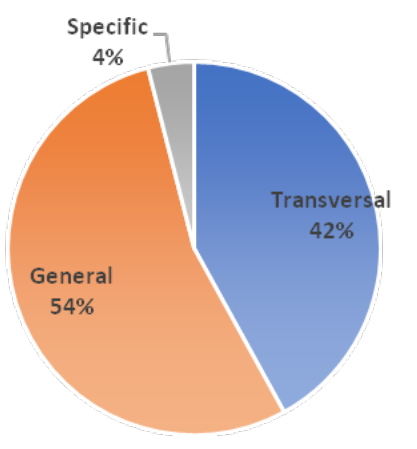

Figure 3. Proportion of EntreComp competences categorised as transversal, general and specific

Table 1 shows the general results obtained for the representation of the EntreComp competences in the curricula of undergraduate translation degrees in Spain, expressed as percentages.

\begin{tabular}{|c|c|c|c|c|}
\hline & \multirow[t]{2}{*}{ Competence } & \multirow[t]{2}{*}{ Total (\%) } & \multicolumn{2}{|c|}{ By type of University (\%) } \\
\hline & & & Public & Private \\
\hline \multirow{7}{*}{ 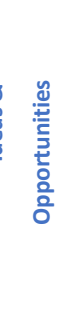 } & Spotting opportunities & 6.25 & 0.00 & 18.18 \\
\hline & Creativity & 56.25 & 61.90 & 45.45 \\
\hline & Vision & 0.00 & 0.00 & 0.00 \\
\hline & Valuing ideas & 6.25 & 0.00 & 18.18 \\
\hline & Ethical and sustainable thinking & 6.25 & 9.52 & 0.00 \\
\hline & Self-awareness and self-efficacy & 6.25 & 0.00 & 9.09 \\
\hline & Motivation and perseverance & 12.50 & 4.76 & 27.27 \\
\hline \multirow{4}{*}{ 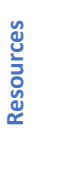 } & Mobilising resources & 100 & 100 & 100 \\
\hline & Financial and economic literacy & 3.13 & 4.76 & 0.00 \\
\hline & Mobilising others & 0.00 & 0.00 & 0.00 \\
\hline & Taking the initiative & 46.88 & 47.62 & 45.45 \\
\hline \multirow{4}{*}{ 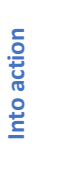 } & Planning and management & 50.00 & 57.14 & 63.64 \\
\hline & Coping with uncertainty, ambiguity and risk & 0.00 & 0.00 & 0.00 \\
\hline & Working with others & 90.63 & 90.48 & 90.91 \\
\hline & Learning through experience & 100 & 100 & 100 \\
\hline
\end{tabular}

Table 1. Percentages of EntreComp framework competences envisaged in curricula of undergraduate translation degrees in Spain.

Following this overview of the most general results derived from our analysis, we present and discuss specific results for the three interrelated competence areas that make up the EntreComp framework: 'ideas and opportunities', 'resources' and 'into action'.

\subsection{Ideas and Opportunities}

The ideas and opportunities area comprises the following entrepreneurial competences: spotting opportunities, creativity, vision, valuing ideas, and ethical and sustainable thinking. These competences are related to using the imagination to identify opportunities for creating value, developing creative and purposeful ideas, working towards a personal vision of the future, making the most of ideas and opportunities, and assessing the consequences and impact of putting them into prac- 
tice. Except for 'creativity', which is incorporated in 53\% of the analysed curricula, the results for this area are very poor, particularly when considering only explicit references made to the EntreComp competences. Actually, not a single degree incorporates any competence related to vision in their curricula, and only $6.25 \%$ of the degrees incorporate competences related to spotting opportunities, valuing ideas or ethical and sustainable thinking. Specifically, 'spotting opportunities' is present in two degrees designed by private universities that combine translation and languages. This accounts for only $12.5 \%$ of translation degrees in Spain. Actually, the competences with no representation in the curricula of public universities increase up to three: spotting opportunities, vision and valuing ideas.

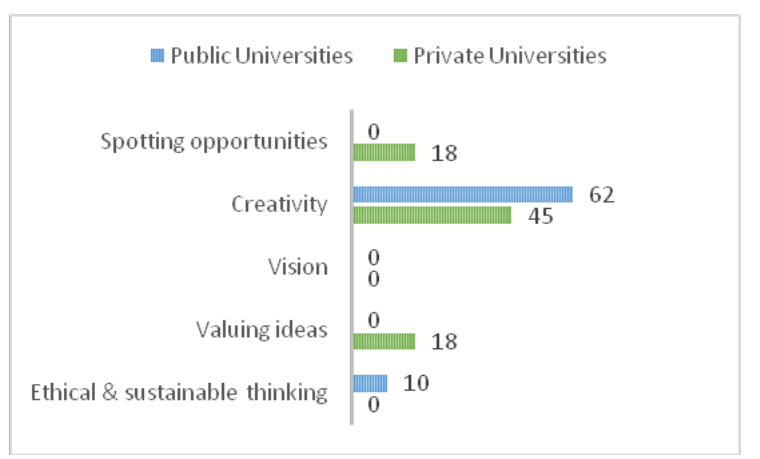

Figure 4. Ideas and opportunities competences in translator education curricula in public and private universities.

The situation improves slightly for 'ethical and sustainable thinking' when a flexible approach to EntreComp is taken and the ethical and sustainable attributes are considered separately. Actually, ethical thinking is envisaged in $75 \%$ of the curricula, sustainable thinking is envisaged in $6.25 \%$ and ethical and sustainable thinking is envisaged in $6.25 \%$ of the curricula.

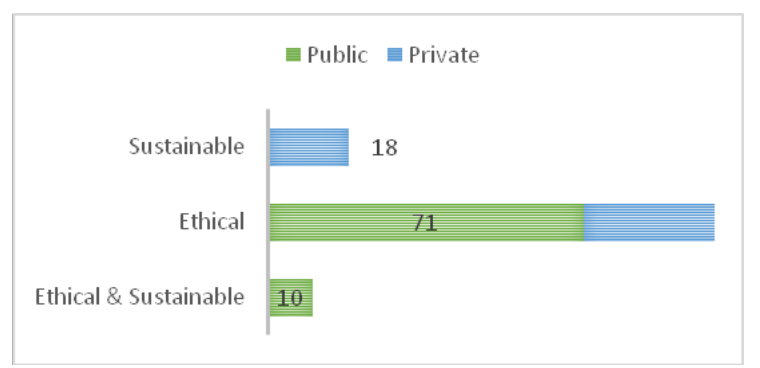

Figure 5. Ethical and sustainable thinking competence in translator education in public and private universities.

The combination of the three possibilities amounts to almost $90 \%$ of presence of some of the elements in this competence, with wide presence of ethical behaviour. This implies that students are compelled to act responsibly, but not to reflect on how sustainable their goals are or on the course of the action chosen.

\subsection{Resources}

The resources area comprises five entrepreneurial competences, namely self-awareness and selfefficacy, motivation and perseverance, mobilising resources, financial and economic literacy, and mobilising others, which are related to believing in oneself, staying focussed and keep developing, gathering and managing resources, developing financial and economic know-how and inspiring and convincing others. As in the ideas and opportunities area, a rigid approach that considers 
only explicit reference to the entrepreneurial competences included in the resources area yields poor results for most competences considered.

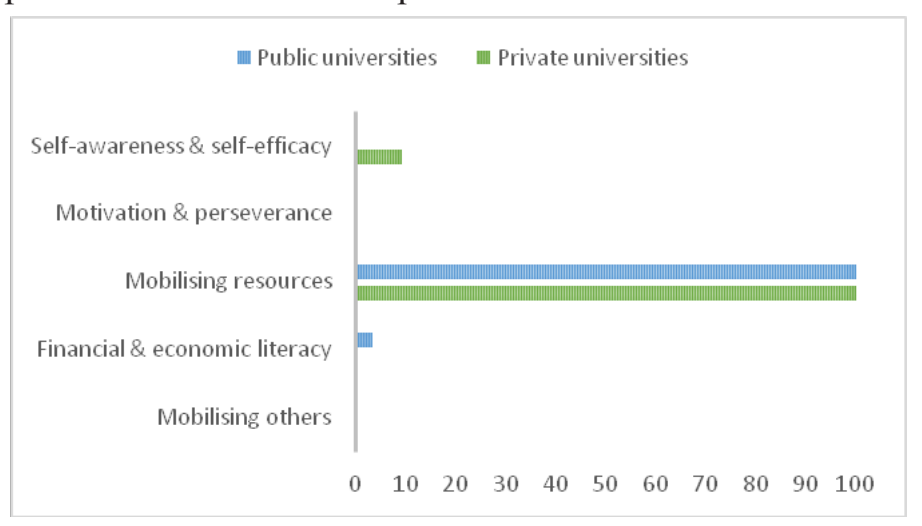

Figure 6. Resources area competences in translator education in public and private universities.

As shown in figure 6, all the Spanish universities incorporate the 'mobilising resources' competence in their curricula. Conversely, no university incorporates 'motivation and perseverance' or 'mobilising others', only one university incorporates 'self-awareness and self-efficacy', and only two universities incorporate 'financial and economic literacy'.

The results for motivation and perseverance slightly improve when the competence splits into two sub-competences, insofar as motivation is present as a transversal competence in two degrees offered by private universities that combine translation with languages. This accounts for $12.5 \%$ of translation degrees in Spain.

In $40 \%$ of the analysed translator education curricula, motivation is present, but linked exclusively to quality. Yet, we cannot apply a flexible approach here because EntreComp understands motivation as the ability to regulate behaviour to stay driven and achieve the benefits of turning ideas into action, be determined and be capable of rewarding initiative, effort, and achievement appropriately within a team or organisation, which covers many areas apart from quality. The same applies to perseverance, since there is no hint of allusion to patience or resilience under pressure or adversity in current curricula.

Similarly, 'financial and economic literacy' would apparently benefit from introducing a flexible approach to the interpretation of competence, insofar as $90 \%$ of the universities include competences related to the economic and professional aspects of translation in their curricula. However, a detailed analysis of the actual implementation of this competence reveals that almost $70 \%$ of the degrees develop economic and professional literacy through a single module focused on learning how to create a new business, prepare bills, pay taxes or manage projects. This approach lies far from the EntreComp framework descriptors, which relate financial and economic literacy to putting in place and evaluating financial decisions over time, making sure the valuecreating activity developed can last over the long term, or judging opportunities to become an investor. Actually, the current approach to the financial and economic literacy competence in Spanish translator education programmes has more to do with getting and managing the resources to support an idea, an opportunity or a new business, or developing effective time-management procedures for the translation activity, which are some of the aspects included in 'mobilising resources'.

According to these findings, translator students in Spain are being trained for mobilising resources. This will help them find, manage and make the most of the material, non-material, digital, technical, legal and tax resources and competences required at any stage. However, this is only one of the five components of the resources area identified in EntreComp. Based on our analysis, translator education programmes in Spain are neglecting highly important skills for work life envisaged in the other four competences included in the resources area, among which reflec- 
ting on needs and aspirations, identifying and assessing strengths and weaknesses, being determined and resilient, estimating the cost of turning an idea into a value-creating activity, and planning and managing financial decisions.

\subsection{Into action}

The into action area comprises the last five entrepreneurial competences, namely taking the initiative, planning and management, coping with uncertainty, ambiguity and risk, working with others, and learning through experience, which are related to initiating processes and acting independently to achieve goals; prioritising, organising and monitoring tasks, making decisions in uncertain situations, collaborating and networking, and learning by doing.

This is the competence area with the best results, which are particularly good for three competences: planning and management, working with others and learning through experience.

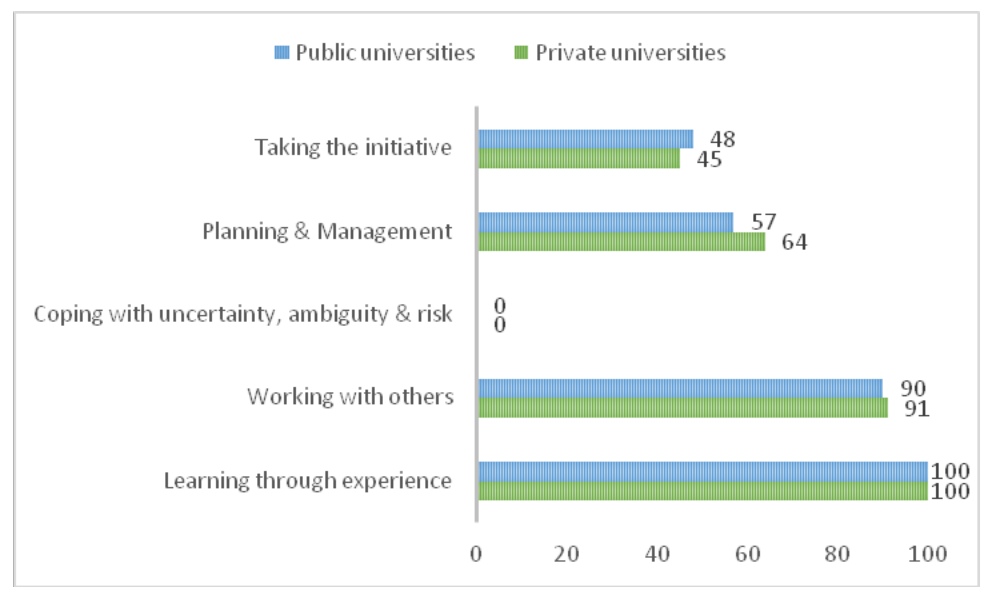

Figure 7. 'Into action' competences in translator education in public and private universities.

As shown in figure 7, very similar results are obtained for public and private universities in this area, which allows us to treat data as a single dataset. Overall, learning through experience or learning by doing is incorporated as a competence in $100 \%$ of the curricula, whereas 'working with others' is incorporated in $90 \%$ of the degrees.

Yet, we must clarify that the 'working with others' competence envisaged in Spanish curricula in translation does not explicitly include the 'value creation' component required for real entrepreneurship to occur, nor does it include the 'conflict resolution' dimension envisaged in EntreComp, which is necessary to develop emotional intelligence and avoid rejection of team projects by students.

Good results are also obtained for 'planning and management' and 'initiative', which are incorporated in $47 \%$ and $50 \%$ of the curricula, respectively. The results for planning and management substantially improve under a flexible approach, i.e. by including specific translation project planning and management competences in the main planning and management competence. Actually, the percentage of degrees that develop competences related to defining goals, planning, organising and monitoring progress increase up to $90 \%$ when the transversal, general and specific competences are considered jointly.

Conversely, 'coping with uncertainty, ambiguity and risk' is not incorporated as a competence in any of the degrees in translation offered by Spanish universities. Finally, as stated at the beginning of this section, $37.5 \%$ of the undergraduate degrees combine 'Taking the initiative' and 'entrepreneurship' into a single transversal or general competence. 
According to these findings, translator students in Spain develop to some extent the competences related to learning by doing, working with others, initiative and planning and management. This provides a good basis for implementing a project-based learning approach, which provides an excellent framework for incorporating other entrepreneurial competences. These results are in agreement with the abundant research conducted in the field of collaborative learning in translation (see Huertas 2011, Kiraly 2012, Huertas 2013, Mitchell-Schuitevoerder 2013, García/Veiga 2015, Hagemann 2016, Kiraly et al. 2016, Maruenda Bataller/Santaemilia Ruiz 2016, Massey 2019 or Kiraly et al. 2019).

\section{SWOT analysis and proposals for action}

As suggested by Kormakova et al. (2015: 4), traditional teaching and learning can be meaningfully adapted to the needs of entrepreneurship competence, particularly by innovative and wellaligned teaching and assessment methods that help educators achieve creative entrepreneurial development.

Based on both this premise and the findings reported in the above section, we present an analysis of the strengths, weaknesses, opportunities and threats of the current situation of entrepreneurial competence in Spanish translator education that will allow us to make the decisions required to improve the status quo.

\subsection{SWOT analysis}

\begin{tabular}{|c|c|}
\hline \multicolumn{2}{|l|}{ SWOT ANALYSIS } \\
\hline Strengths & Weaknesses \\
\hline $\begin{array}{l}\text { - Strong focus on learning by doing in groups. } \\
\text { - Successful implementation of team work. } \\
\text { - Strong focus on mobilising resources. } \\
\text { - Strong focus on ethical behaviour. } \\
\text { - Good approach to 'into action' competence. } \\
\text { - Experience in competence implementation. } \\
\text { - Experience in curricula design. }\end{array}$ & $\begin{array}{l}\text { - Outdated curricula. } \\
\text { - Difficulties for course planning and assessment. } \\
\text { - Disregard of non-cognitive skills. } \\
\text { - Neglection of ideas and opportunities. } \\
\text { - Focus on value acquisition, instead of value } \\
\text { creation. } \\
\text { - Education for entrepreneurship, not through } \\
\text { entrepreneurship. } \\
\text { - Considering competences as administrative } \\
\text { work. } \\
\text { - Inappropriate facilities. }\end{array}$ \\
\hline Opportunities & Threats \\
\hline $\begin{array}{l}\text { - Curricula with broad competences that } \\
\text { encompass EntreComp competences. } \\
\text { - Abundant literature on entrepreneurial teaching. } \\
\text { - Europe's commitment to entrepreneurial } \\
\text { teaching. } \\
\text { - EntreComp framework. } \\
\text { - Implementation of pilot projects. } \\
\text { - Possibility of curricula renewal. }\end{array}$ & $\begin{array}{l}\text { - Insufficient teacher training. } \\
\text { - Rigid course planning and assessment schemes. } \\
\text { - Lack of incentives to teachers. } \\
\text { - Reluctance to change the approach to curricula } \\
\text { design. } \\
\text { - Reduced number of entrepreneurial teachers. } \\
\text { - Disregard of transversality. } \\
\text { - Insufficient connection between students and } \\
\text { the outside world. } \\
\text { - Inconclusive results in pilot projects. }\end{array}$ \\
\hline
\end{tabular}

Table 2. SWOT analysis for development of entrepreneurial competence in Spanish Translator Education 
Reviewing the curricula of Spanish undergraduate degrees in translation and interpretation has brought to light the following strengths within the current framework: the curricula of the different modules show a strong focus on ethical behaviour, mobilising resources, learning by doing, team-work and planning. Based on these strengths, proposals for action can be further developed.

\subsection{Proposals for action}

The spotted strengths provide an excellent starting point for incorporating the EntreComp entrepreneurial competences in the curricula through experiential collaborative learning, an appropriate learning setting (Massey/Braendli 2016) that allows for the integration of the four dimensions required in order to achieve progression: team-based approach, focus on value creation, connecting students with the outside world and letting students act on their knowledge and skills.

First, collaborative projects facilitate the integration of competences related to the ideas and opportunities' area, such as spotting opportunities, vision, creativity and valuing ideas, provided that some freedom is given to students to define their own project by identifying needs and challenges, develop several ideas, experiment with innovative approaches, imagine how their ideas could be put into action, recognise the potential of all the ideas considered and assess which could be put into action.

Second, with regard to the 'resources' competences, collaborative projects promote self-awareness and self-efficacy, as suggested by Haro Soler (2019), motivation and perseverance (Way 2019), mobilising others and taking the initiative, insofar as collaborating with others requires reflection on individual and group needs, determination and patience to achieve individual and group aims, enthusiasm to engage other people in the project, and resilience to adversity and temporary failure. Resilience to adversity and temporary failure have been used as pedagogical resources in translation education by Washbourne (2015). In this area, emotions become even more relevant. Sharing these processes with peers and mentors or teachers adds learning value to the experience, since emotions are key to attributing meaning to learning experiences, as suggested by (Dirkx 2001).

Third, as per the 'into action' competences, which are already satisfactorily included in the curricula, particular attention should be payed to creating value for the outside world, which would foster the capability to cope with uncertainty, ambiguity and risk, take decisions when the results of the decisions are uncertain, when the information available is partial or ambiguous, or when unintended outcomes arise. In this sense, Hubscher-Davidson (2018) claims that tolerance of ambiguity is essential for translators to be successful and links this competence to emotional intelligence and job satisfaction. Moreover, collaborating with the outside world requires initiating processes that create value for others: collaborating with local governments and agencies by providing them with guidelines to successfully translate their documents, working with non-profit organisations to help them spread knowledge and ideas, or collaborating in the development and translation of Free and Open Source Software are some examples that have been successfully implemented in undergraduate translation degrees in Spain.

The stimulus of the Entrepreneurship 2020 Action Plan and the experience gained from pilot projects provides us with an opportunity to engage in the described approach. This approach focuses on value creation and it can be incorporated in translator education without making changes in the curriculum, considering that the competences envisaged in current translator education programmes are broad and encompass the more specific competences included in the framework model.

Moreover, the described approach compensates for some of the spotted weaknesses, among which disregard of non-cognitive skills, neglection of ideas and opportunities, or perception of competences as administrative work. Still, some weaknesses would persist, among which lack of specific training for teachers or inappropriate facilities for collaborative work. The abundant literature on collaborative learning (see Huertas 2011, Kiraly 2012, Huertas 2013, Mitchell-Schuite- 
voerder 2013, García/Veiga 2015, Hagemann 2016, Kiraly et al. 2016, Maruenda Bataller/Santaemilia Ruiz 2016, Massey 2019 or Kiraly et al. 2019) and the experience gained from European Pilot Projects could compensate for the lack of specific training, whereas other weaknesses, such as difficulties in collaborative work assessment, could be further compounded because of the demonstrated challenges of entrepreneurial competence assessment. To alleviate this weakness, the EntreComp model proposes different levels of proficiency aligned with the corresponding learning outcomes, which should be useful for building a specific model that help educators assess progression in entrepreneurial competence acquisition in translation degrees.

Finally, we would still have translator education programmes with outdated curricula, in the sense that they do not conform to the European entrepreneurship education guidelines. This could be solved by undertaking a reform of the undergraduate translation degrees using the experience in EHEA curricula design and competence implementation gained by Spanish Universities in the last ten years. Notwithstanding, the detected threats would be particularly menacing in a degreereform context, and specific actions should be envisaged if translation and interpretation degrees were reformed.

\section{Conclusions}

The results demonstrate that the entrepreneurship competences envisaged in the EntreComp framework model are underrepresented in Spanish undergraduate degrees in translation and interpretation, with no significant differences between public and private universities or between degrees that offer translation and interpretation training alone or combined with languages or communication. The vast majority of current curricula were designed between 2008 and 2010 and reflect the perspective of entrepreneurship and leadership prevailing at the time, which is far less specific than the current perspective and focuses on leadership, moral values and ethics, communication and also the ability to adapt to new work contexts. Actually, these curricula often emphasise skills such as autonomy, teamwork and collaboration, communication, sense of responsibility, organisation and management and decision-making, which can be included in a wide definition of entrepreneurship. While some of these competences, such as autonomy, responsibility and self-learning can be considered as prerequisites in the field of higher education, elements such as ambiguity, uncertainty and ability to learn from failure, which have been explicitly approached in tertiary education case studies (Komarkova et al., 2015:27), are almost neglected in translator education and translation education research (Bolaños-Medina 2014, Washbourne 2015, HubscherDavidson 2018).

Despite the general approach to entrepreneurship in current translator education programmes, some competences match those included in the EntreComp framework. Thus, 'mobilising resources' and 'learning through experience' are the pillars of the current curricula, and 'planning and management' is well represented. Yet, learning through experience is very often understood at a foundation or intermediate level, in which students focus exclusively on applying what they have learned to a practical task or activity, with scarce reflection on what or how they have learned and no sense of creating value for others.

The competences in the 'ideas and opportunities' area are the least represented competences, with substantial neglection of spotting opportunities, valuing ideas, vision and sustainable thinking. The same applies to some 'resources' competences, such as self-awareness and self-efficacy, motivation and perseverance and mobilising others, and to the 'into action' competence labelled 'coping with uncertainty, ambiguity and risk'. Considering that the labels for these three areas aim at stressing that entrepreneurship competence is the ability to transform ideas and opportunities into action by mobilising resources, our results suggest that our students develop the ability to mobilise resources to do things in a planned manner, but leave the ideas behind and are unable to spot opportunities or mobilise others. This would partially explain why self-employment among Spanish graduates accounts for less than 20\% according to Galán Mañas (2017). 
In spite of these weaknesses, our analysis has revealed strengths and opportunities in the current situation that would allow for the implementation of the EntreComp framework model in current translator education curricula, mainly because of the relevance of team-based work and its potential for entrepreneurship competence development. Such a change would involve moving from educating for entrepreneurship to educating through entrepreneurship.

Alternatively, entrepreneurial learning could be properly incorporated in translator education by reforming current curricula with the aid of the Entrepreneurship Competence framework. This would involve making universities more entrepreneurial, in accordance with the Entrepreneurship 2020 Action Plan. Yet, our study should be extended to other European countries in order to obtain a more comprehensive view of the actual implementation of the EntreComp framework in translator education in Europe before reforming Spanish curricula. For the time being, let the small steps count.

\section{References}

Álvarez Álvarez, Susana/Arnáiz Urquiza, Verónica 2017: Translator and interpreting graduates under construction: do Spanish translation and interpretation studies curricula answer the challenges of employability? In The Interpreter and Translator Trainer 11(2-3), 139-159.

Aruwa, Suleiman 2006: The business entrepreneur: entrepreneurial development, small and medium enterprises (2nd Ed.). Kaduna: Entrepreneurship academy publishing.

Biggs, John/Tang, Catherine 2011: Teaching for Quality Learning at University, Berkshire: Open University Press.

BIS - Department for Business, Innovation and Skills 2015: BIS Research Paper No. 236. Entrepreneurship Skills: literature and policy review. London: Department for Business, Innovation and Skills.

Blenker, Per/Elmholdt, Stine /Frederiksen, Signe /Korsgaard, Steffen/Wagner, Kathleen 2014: Methods in entrepreneurship education research: a review and integrative framework. In Education and Training, 56(8/9), 607-715.

Bolaños Medina, Alicia 2014: Self-efficacy in translation. In Translation and Interpreting Studies 9(2), 197-218.

Bolaños Medina, Alicia/Núñez, Juan 2018: A Preliminary Scale for Assessing Translators' Self-efficacy. In Across Languages and Cultures 19(1), 53-78.

Calvo, Elisa/Kelly, Dorothy/Morón-Martín/Marian 2010: A Project to Boost and Improve Employability Chances among Translation and Interpreting Graduates in Spain. In Pellat Valerie/Griffiths, Catherine/Wu Shao-Chuan (eds.), Teaching and Testing Interpreting and Translating. Bern: Peter Lang, 209-226.

Chouc, Fanny/Calvo, Elisa 2011: Embedding employability in the curriculum and building bridges between academia and the work-place: a critical analysis of two approaches. In La Linterna del Traductor 4, 71-86.

Del Giudice, Manlio 2014: Female Young Entrepreneurship: Practical Evidence. In Del Giudice, Manlio/Della Peruta, Maria Rosaria/Carayannis, Elias Carayannis (eds.), Student Entrepreneurship in the Social Knowledge Economy. Successful Cases and Management Practices. Basel: Springer, 127-141.

Dirkx, John 2001: The power of feelings: Emotion, imagination, and the construction of meaning in adult learning. In New directions for adult and continuing education 2001 (89), 63-72.

Drucker, Peter Ferdinand 2007: Management challenges for the 21st century. London: Butten/vorth Heinemann.

EMFD 2008: Best Practices and Pedagogical Methods in Entrepreneurship Education in Europe Quality of Entrepreneurship Programmes in Europe. [online] https://www.efmd.org/projects-test?download=10:13-qepe-best-practices (accessed 14 April 2019).

European Commission 2006: Socrates Report 2006 - Best Practices \& Pedagogical Methods in Entrepreneurship Education in Europe. EU Commission - DG Education and culture.

European Commission 2008a: Entrepreneurship in Higher Education, especially within non-business studies. Brussels: Directorate-General for Enterprise and Industry.

European Commission 2008b: Survey of Entrepreneurship in Higher Education in Europe. Brussels: Directorate-General for Enterprise and Industry.

European Commission 2012: Effects and impact of entrepreneurship programmes in higher education. Brussels: Directorate-General for Enterprise and Industry.

European Commission 2013: Entrepreneurship 2020 Action Plan. Brussels: European Commission.

European Commission 2014: Entrepreneurship Education: A Guide for Educators. Brussels: European Commission. European Commission 2015: Entrepreneurship Education: A road to success. 13 case studies. Luxembourg: Directorate-General for Enterprise and Industry. 
European Commission 2017: European Master's in Translation. Competence Framework 2017. Brussels: European Commission.

European Parliament and Council 2006: Recommendation of the European Parliament and of the Council of 18 December 2006 on key competences for lifelong learning. In Official Journal of the European Union, (2006/962/EC).

Eurydice 2012: Entrepreneurship Education at School in Europe. National Strategies, Curricula and Learning Outcomes. Brussels: Education, Audiovisual and Culture Executive Agency.

Galán Mañas, Anabel 2017: Vinculación de las prácticas curriculares con la realidad laboral de los graduados en Traducción e Interpretación. In VIII Congreso Internacional de la Asociación Ibérica de Estudios de Traducción e Interpretación (2017 March 8-10). Alcalá de Henares.

Galán Mañas, Anabel 2019: Professional portfolio in translator training: professional competence development and assessment. In The Interpreter and Translator Trainer 13(1), 44-63.

García González, Marta/Veiga Díaz, María Teresa 2015: Guided Inquiry and Project-Based Learning in the field of specialised translation: a description of two learning experiences. In Perspectives. Studies in Translatology 23(1), 107-123.

Gartner, William 1990: What are we talking about when we talk about entrepreneurship? In Journal of Business Venturing 5, 15-28.

GHK 2011: Mapping of teachers 'preparation for entrepreneurship education. Brussels: DG Education and Culture.

Gieure Sastre, Clara 2016: El traductor e intérprete emprendedor: análisis de la supervivencia de las empresas y los empresarios autónomos. Unpublished PhD Thesis. Alicante: Universidad de Alicante. [online] http://rua.ua.es/ dspace/handle/10045/55629 (accessed 7 April 2019).

Hagemann, Susanne 2016: (Non-)Professional, Authentic Projects? Why Terminology Matters. In Kiraly, Don (ed.), Towards Authentic Experiential Learning in Translator Education. Germany: V\&R Unipress/Mainz University Press, 33-52.

Haro Soler, María del Mar 2017: Teaching practices and translation students' self-efficacy: a qualitative study of teachers' perceptions. In Current Trends in Translation Teaching in Translation Teaching and Learning E 4, 198-228.

Haro Soler, María del Mar 2019: La colaboración entre futuros traductores: su impacto en las creencias de autoeficacia para traducir. In Mutatis Mutandis 12(2), 330-356.

Haro Soler, María del Mar/Kiraly, Don 2019: Exploring self-efficacy beliefs in symbiotic collaboration with students: an action research project. In The Interpreter and Translator Trainer 13(3), 255-270.

Hubscher-Davidson, Severine 2018: Do Translation Professionals Need to Tolerate Ambiguity to be Successful? A Study of the Links between Tolerance of Ambiguity, Emotional Intelligence and Job Satisfaction. In Lacruz, Isabel/ Jääskeläinen, Riitta (eds), Innovation and Expansion in Translation Process Research. American Translators Association Scholarly Monograph Series (XVIII). Philadelphia: John Benjamins, 77-103.

Huertas Barros, Elsa 2011: Collaborative learning in the translation classroom: Preliminary survey results. In The Journal of Specialised Translation 16(1), 42-60.

Huertas Barros, Elsa 2013: La competencia interpersonal en la formación de traductores en España: Un estudio empirico-descriptivo del trabajo colaborativo durante la primera etapa de formación en traducción e interpretación $\mathrm{PhD}$ Thesis. Granada: Universidad de Granada [online] https://hera.ugr.es/testsugr/22074508.pdf (accesed 1 April 2019).

King, Hailey 2016: Translator Education in Context: Learning Methodologies, Collaboration, Employability, and Systems of Assessment. PhD Thesis. RMIT University. [online] https://researchbank.rmit.edu.au/eserv/rmit:162101/ King.pdf (accessed 16 March 2019).

Kiraly, Don 2012: Growing a Project-Based Translation Pedagogy: A Fractal Perspective. In Meta 57(1), 82-95.

Kiraly, Don/Hofmann, Sascha 2016: Towards a Post-positivist Curriculum Development Model for Translator Education. In Kiraly, Don (ed.), Towards Authentic Experiential Learning in Translator Education. Germany: V\&R Unipress/Mainz University Press, 67-88.

Kiraly, Don/Massey, Gary/Hofmann, Sascha 2018: Beyond Teaching: Towards Co-Emergent Praxis in Translator Education. In Ahrens, Barbara/Hansen-Schirra, Silvia/Krein-Kühle, Monika/Schreiber, Michael/Wienen, Ursula (eds.), Translation - Didaktik - Kompetenz. Berlin: Frank \& Timme Verlag, 11-64.

Klerk, Gerda/Kruger, Sean 2002: The driving force behind entrepreneurship: an exploratory perspective. In Füglistaller, Urs/Pleitner, Hans Jobst/Volery, Thierry/Weber, Walter (eds.), Radical Change in the World-Will SMEs Soar or Crash Profit, St. Gallen: KMU Verlag HSG, 469-476, 469-476.

Komarkova, Ivana/Conrads, Johannes/Collado, Antonio 2015: Entrepreneurship Competence: An Overview of Existing Concepts, Policies and Initiatives. In-depth case studies report. Luxembourg: Publication Offices of the European Union. 
Maruenda Bataller, Sergio/Santaemilia, José 2016: Project-Based Learning and Competence Assessment in Translation Training. In Carrio-Pastor, María Luisa (ed.), Technology Implementation in Second Language Teaching and Translation Studies. New Tools, New Approaches, New Frontiers in Translation Studies. Singapore: Springer.

Massey, Gary 2019: Learning to Learn, Teach and Develop. In inTRAlinea Special Issue: New Insights into Translator Training [online] http://www.intralinea.org/print/article_specials/2429 (accessed 25 March 2019).

Massey, Gary/Braendli, Barbara 2016: Collaborative feedback flows and how we can learn from them: Investigating a synergetic learning experience in translator education. In Kiraly, Don (ed.), Towards Authentic Experiential Learning in Translator Education. Germany: V\&R Unipress/Mainz University Press, 177-199.

MECD 2015: La educación para el emprendimiento en el sistema educativo español. Año 2015. Madrid: Ministerio de Educación, Cultura y Deporte.

Mesquita, Cristina/ Lopes, Rui Pedro/ Bredis, Cristina 2016: Entrepreneurship in Higher Education as a Horizontal Competence". In Peris-Ortiz, Marta/Alonso Gómez, Jaime/Vélez-Torres, Francisco/ Rueda-Armengot, Carlos (eds.), Creating an Action-Learning Environment through Educational Learning Tools. Basel: Springer.

MICT 2019: Autodiagnóstico de actitudes emprendedoras [online]. Ministerio de Industria, Comercio y Turismo. [online] https://autodiagnosticos.ipyme.org/Emprendedores/ (accessed 10 March 2019).

Mitchell-Schuitevoerder, Rosemary 2013: A project-based methodology in translator training. In Way, Catherine/ Vandepitte, Sonia/Meylaerts, Reine/Bartlomiejczyk, Magdalena (eds.), Tracks and Trends in Translation Studies: Selected papers from the EST Congress. Amsterdam: John Benjamins, 127-142.

Mwasalwiba, Ernest Samwel 2010: Entrepreneurship education: A review of its objectives, teaching methods and impact indicators. In Education and Training 52(1), 20-47.

Olalla Soler, Christian 2019: Bridging the gap between translation and interpreting students and freelance professionals. The mentoring programme of the Professional Association of Translators and Interpreters of Catalonia. In The Interpreter and Translator Trainer 13(1), 64-85.

Pihie, Zaidatol Akmaliah Lope/Bagheri, Afsaneh 2001: Teachers' and Students' Entrepreneurial Self-efficacy: Implication for Effective Teaching Practices. In Procedia. Social and Behavioural Sciences, 29, 1071-1080.

Redford, Dana T. 2015: Entrepreneurial teacher training in Europe: an overview of European policies and developments. In Journal for Educators, Teachers and Trainers 6(2), 17-34.

Rico Pérez, Celia/García Aragón, Álvaro 2016: Análisis del sector de la traducción en España (2014-15). Madrid: Universidad Europea de Madrid.

Sammut-Bonnici, Tanya/Galea, David 2015: Swot Analysis. In Wiley Encyclopaedia of Management, 12, 1-2. Chichester: Wiley.

Shane, Scott/Venkataram, Sankaran 2007: The Promise of Entrepreneurship as a Field of Research. In Cuervo, Álvaro/ Ribeiro, Domingo/Roig, Salvador (eds.), Entrepreneurship. Berlin, Heidelberg: Springer.

Sousa, María José 2018: Entrepreneurship Skills Development in Higher Education Courses for Teams Leaders. In Administrative Sciences 8 (2), 18, 15 pages.

Souza, Clair 2001: Empreendedorismo e Capacitação Docente: uma sintonia possível. Master's Dissertation. Universidade de Santa Catarina, Paraná. [online] https://core.ac.uk/download/pdf/30360671.pdf (accessed 7 April 2019)

Torres Hostench, Olga 2012: Occupational Integration Training in Translation. In Meta, 57 (3), 787-811.

Veiga Díaz, María Teresa/García González, Marta 2016: Constructively Aligned Assessment: An Integral Approach to Translation Teaching and Learning. In Meta 61(2), 276-298.

Washbourne, Kelly 2015: Learning to fail: unsuccessful translation as pedagogical resource. In Current Trends in Translation Teaching in Translation Teaching and Learning E 2, 285-320.

Way, Catherine 2019: Fostering Translator Competence: The Importance of Effective Feedback and Motivation for Translator Trainees. In inTRAlinea Special Issue: New Insights into Translator Training [online] http://www.intralinea.org/print/article_specials/2430 (accessed 23 March 2019). 